\title{
Tree-ring investigations into changing climatic responses of yellow-cedar, Glacier Bay, Alaska
}

\author{
Gregory C. Wiles, Colin R. Mennett, Stephanie K. Jarvis, Rosanne D. D'Arrigo, \\ Nicholas Wiesenberg, and Daniel. E. Lawson
}

\begin{abstract}
Yellow-cedar (Callitropsis nootkatensis (D. Don) Örsted ex D.P. Little) is in a century-long decline coinciding with the end of the Little Ice Age (LIA). The leading hypothesis explaining this decline is a decrease in insulating snowpack due to warming and increased susceptibility to damaging frosts in the root zone. A ring-width series from yellow-cedar on Excursion Ridge (260 m a.s.1.) in Glacier Bay National Park and Preserve, Alaska, and another from trees on Pleasant Island (150 m a.s.l.) in the Tongass National Forest in Icy Strait were compared with regional monthly temperature and precipitation data from Sitka, Alaska, to investigate the changing growth response to temperature at these sites. Comparisons with monthly temperatures from 1832 to 1876 during the end of the Little Ice Age show that the high-elevation Excursion Ridge and the low-elevation Pleasant Island sites strongly favored warmer January through July temperatures. Both tree populations have markedly changed their response from a positive to a strong negative correlation with January through July temperatures since 1950. This strong negative response to warming by the yellow-cedar together with a positive relationship with total March and April precipitation suggests that these yellow-cedar sites may be susceptible to decline. Furthermore, these analyses are consistent with the hypothesis that the yellow-cedar decline is linked to decreased snowpack.
\end{abstract}

Résumé : Le faux-cyprès de Nootka (Callitropsis nootkatensis (D. Don) Örsted ex D.P. Little) connaît une période de dépérissement qui dure depuis un siècle et dont le début coïncide avec la fin du Petit Âge glaciaire. La principale hypothèse pour expliquer ce dépérissement est la réduction du couvert nival et de ses propriétés isolantes à cause du réchauffement climatique ainsi que l'augmentation de la sensibilité aux dommages causés par le gel dans la zone des racines. Une série dendrochronologique du faux-cyprès de Nootka provenant d'Excursion Ridge (260 mètres au-dessus du niveau de la mer), dans le parc national de Glacier Bay, en Alaska, et une autre provenant d'arbres sur Pleasant Island (150 mètres au-dessus du niveau de la mer) dans la forêt nationale de Tongass à Icy Strait ont été comparées aux données régionales de précipitation et de température mensuelles provenant de Sitka en Alaska pour étudier la variation de la réaction de la croissance à la température dans ces stations. Les comparaisons avec les températures mensuelles de 1832 à 1876, à la fin du Petit Âge glaciaire, montrent que la station d'Excursion Ridge à une altitude élevée et la station de Pleasant Island à plus basse altitude étaient très favorables aux températures plus chaudes de janvier à juillet. Les deux populations d'arbre ont nettement changé leur réaction passant d'une corrélation positive à fortement négative avec les températures de janvier à juillet depuis 1950. Cette forte réaction négative du faux-cyprès de Nootka combinée à une relation positive avec la précipitation totale des mois de mars et avril indique que ces stations à faux-cyprès de Nootka sont peut-être sensibles au dépérissement. De plus, ces analyses sont compatibles avec l'hypothèse selon laquelle le dépérissement du faux-cyprès de Nootka serait relié à la réduction du couvert nival.

[Traduit par la Rédaction]

\section{Introduction}

Tree mortality caused by biotic and abiotic factors is among the responses of the world's forests to recent climate variations (Adams et al. 2010). The loss of forests has tangi- ble impacts on biogeochemical cycles and the Earth's energy balance and is linked to various feedbacks such as albedo and the carbon cycle (Allen et al. 2010; Adams et al. 2010). Tree mortality along the Gulf of Alaska, where forests represent a significant source of carbon, can potentially have an impact

Received 8 December 2011. Accepted 9 February 2012. Published at www.nrcresearchpress.com/cjfr on 14 March 2012.

G.C. Wiles, C.R. Mennett, and S.K. Jarvis. Department of Geology, The College of Wooster, 1189 Beall Ave, Wooster, OH 44691, USA.

R.D. D'Arrigo. Tree Ring Lab, Lamont-Doherty Earth Observatory, Palisades, NY 10964, USA.

N. Wiesenberg. Department of Geology, The College of Wooster, 1189 Beall Ave, Wooster, OH 44691, USA.

D.E. Lawson. Cold Regions Research and Engineering Lab, 72 Lyme Road, Hanover, NH 03755, USA.

Corresponding author: Gregory C. Wiles (e-mail: gwiles@wooster.edu). 
on the climatic balance of the region (Ryan et al. 2010). Large-scale diebacks of forests reduce carbon sequestration and contribute to warming in the Pacific Northwest and the subarctic region as a whole (Lamb and Wurtz 2009).

One species from Southeast Alaska that is experiencing decline is yellow-cedar (Callitropis nootkatensis (D. Don) Örsted ex D.P. Little). Studies by Little et al. (2004) and Debreczy et al. (2009) suggest that the yellow-cedar, formerly considered to be in the genus Chamaecyparis Spach, may be better assigned as Callitropis nootkatensis; here we will refer to the species as yellow-cedar. This species has a high cold tolerance and is well adapted to cool climates (Schaberg et al. 2005, 2008). Its shallow root systems require a deep snowpack to insulate the roots from hard frosts that can damage roots and potentially lead to the death of the tree (Schaberg et al. 2008). Yellow-cedar is extremely durable, economically valuable (Kelsey et al. 2005), and long-lived, with reports of trees with as many as 1824 annual rings (Pojar and MacKinnon 1994).

Yellow-cedar is common in British Columbia, especially on Vancouver Island, as well as in smaller populations extending as far south as the Oregon-California border (Hennon and Trummer 2001). It occurs at middle to high elevations in the southern part of its range to near sea level farther north along the Alaskan coast (Harris 1990; Pojar and MacKinnon 1994). Yellow-cedar prefers damp, rocky areas, although at the northern edge of its range at lower elevations, it inhabits more boggy settings (Pojar and MacKinnon 1994).

During approximately the last 130 years, the Alaska yellow-cedar has experienced a steep dieback throughout Southeast Alaska and into parts of British Columbia, especially near the border with Alaska (Hennon et al. 2005, 2007). This affected area encompasses over $2300 \mathrm{~km}^{2}$ (Lamb and Wurtz 2009; Snyder et al. 2008) and extends over $500 \mathrm{~km}$ south into British Columbia (Westfall and Ebata 2009). The greatest concentration of yellow-cedar mortality in Southeast Alaska is below $305 \mathrm{~m}$ elevation, whereas farther north, the decline is concentrated at lower elevations, up to $150 \mathrm{~m}$ (Lamb and Wurtz 2009). Concentrations of dead cedar make up to $70 \%$ of the stand's area in some cases (Kelsey et al. 2005; Hennon et al. 2005).

The decline has not been attributed to biotic factors (Hennon et al. 2005; Schaberg et al. 2008), although the cause is not entirely known (Hennon et al. 2007). The start of the decline, ca. 1880-1900 (Hennon et al. 2007), coincides with a period of warming starting at the end of the Little Ice Age (LIA) (Schaberg et al. 2008; Kelsey et al. 2005; Beier et al. 2008). The LIA is a prolonged period of increased glacial activity and general glacial advance and cooler temperatures, although not a continuously cool period (Grove 2001). In Alaska, the LIA began in the early 13th century (Barclay et al. 2009) and ended in the late 1800s. This similarity in timing between the decline and the end of the LIA has led to the development of the leading hypothesis that reduced insulating snowpack has caused premature root dehardening and frost damage (Hennon et al. 2005; Beier et al. 2008; Schaberg et al. 2008; Lamb and Wurtz 2009). Northern elevational limitations on the decline are thought to be consistent with areas of lower snowfall (Lamb and Wurtz 2009). This link to snowfall is further supported by a decrease in active decline rates. In 2007, active decline encompassed 26000 acres, and in 2008, increased snowfall reduced the active decline area to 9000 acres (Lamb and Wurtz 2009).

To further test the link between snowpack and yellowcedar health, a dendroclimatic study was undertaken at two sites of healthy yellow-cedar stands at the northern end of the species range, which are apparently unaffected by the decline. We compared annual tree growth with meteorological data to determine how yellow-cedar has responded to climate over the last 180 years.

\section{Methods}

Yellow-cedar was sampled in the summers of 2007 and 2009 from within Glacier Bay National Park and Preserve on Excursion Ridge (ER; Fig. 1; $58.444^{\circ} \mathrm{N}, 135.594^{\circ} \mathrm{W}$ ) between 250 and $260 \mathrm{~m}$ on a steep, southwest-facing slope. The forest here is a closed-canopy mix with western hemlock (Tsuga heterophylla (Raf.) Sarg.), lodgepole pine (Pinus contorta subsp. contorta), and Sitka spruce (Picea sitchensis (Bong.) Carr.), with most individual yellow-cedar trees less than $0.5 \mathrm{~m}$ in diameter.

An additional site located on Pleasant Island (PI) in the Hoonah Ranger District of Tongass National Forest $\left(58.343^{\circ} \mathrm{N}, 135.571^{\circ} \mathrm{W}\right)$ was sampled at an open-canopy, cedardominated stand consisting of codominant western hemlock and Sitka spruce. Trees were sampled from a flat, marshy area with little to no slope, between 150 and $155 \mathrm{~m}$ elevation. Cedars here were much larger than at ER, with several individual trees more than a metre in diameter. Several large trees showed signs of cultural modification, having been stripped of bark by the Huna Tlingit, the native population in the region (Wayne Howell, personal communication). The majority of the modified trees were still living, having been stripped of portions of their bark from the early 1700s through the early decades of the 1800s (G.C. Wiles, unpublished data). Cores from within the scars and from the opposite side of the trees were included in the final chronologies.

Cores were taken from living and dead trees using a $5 \mathrm{~mm}$ increment borer. At least two cores were taken from each tree at breast height and perpendicular to the slope to minimize the effect of compression wood. Cores were prepared using standard dendrochronological techniques (Stokes and Smiley 1968). The ring widths were measured to the nearest $0.001 \mathrm{~mm}$ using a Velmex measuring system. Crossdating was done visually and then statistically as a means of verification using the computer program COFECHA (Holmes 1983; Grissino-Mayer 2001). Separate ring-width series were developed for both ER and PI. Crossdated and verified series were detrended using the computer program ARSTAN (Cook 1985; Cook and Kairiukstis 1990). Detrending was done using a conservative negative exponential function or a 150year cubic smoothing spline. The decision on which detrending function to use was based on visual inspection of each ring-width series, and care was taken not to introduce or remove trends toward the end of the series. Individual detrended series were then combined into a mean ring-width series, and the standard ring-width chronologies from ARSTAN were used in the climate analyses.

Monthly temperature and precipitation records from the 
Fig. 1. Location map for the tree-ring sites on Excursion Ridge (ER) in Glacier Bay National Park and Preserve and on Pleasant Island (PI) in the Tongass National Forest.

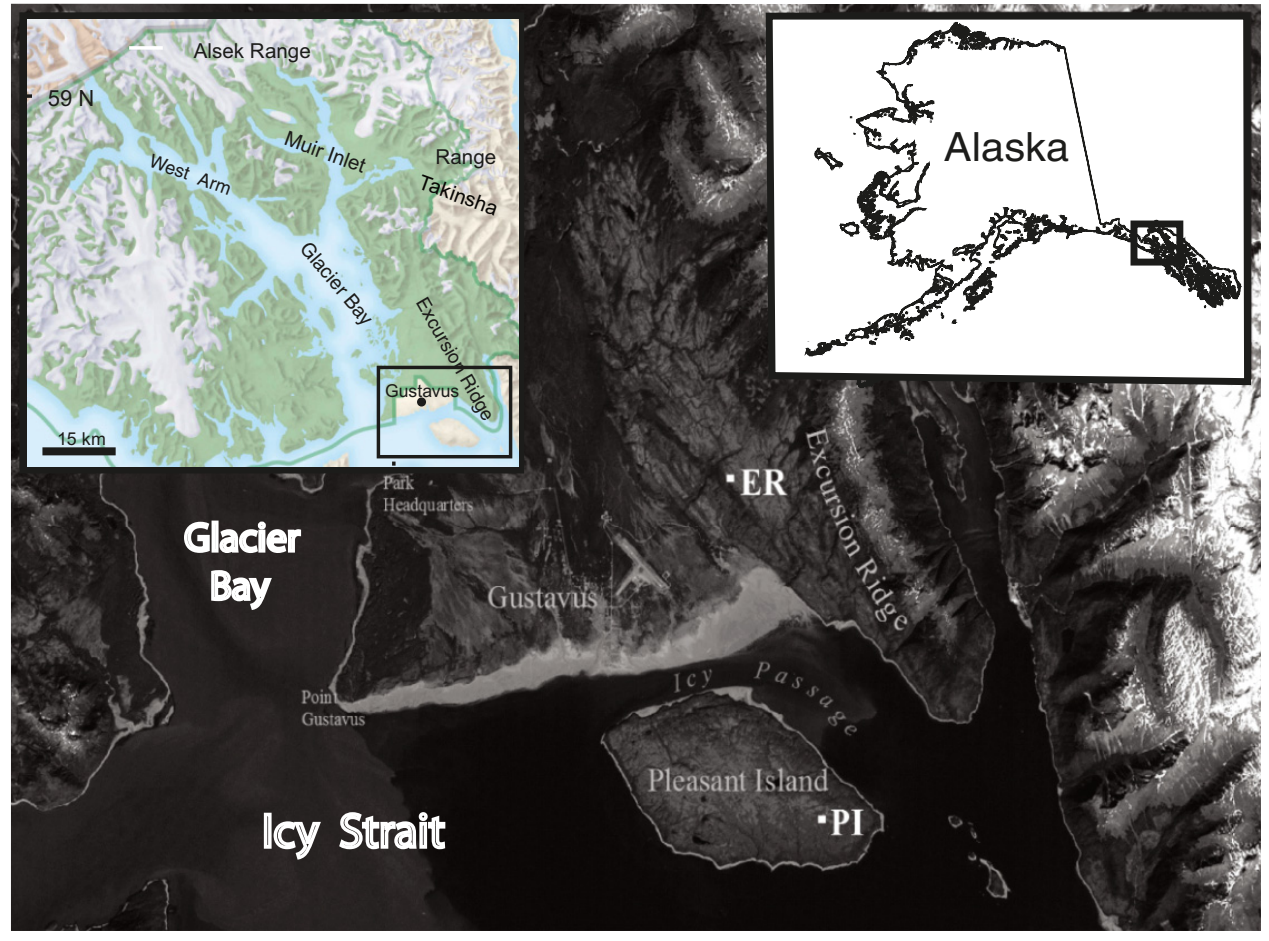

Sitka Magnetic Observatory and precipitation and temperature records from Juneau were extracted from the Global Historical Climate Network (GHCN; Vose et al. 1998) and compared with the annual tree growth. The Sitka record was chosen for its longevity and extension into the LIA (Jones and Bradley 1992). The discontinuous data were divided into three series: one was from the LIA (1832-1876) and the other two were post-LIA temperatures subdivided into the 1900-1950 and 1951-1993 intervals. Juneau records are only available for the post-LIA interval. Growth response to climate was examined using correlation analyses for the dendroclimatic year (previous year's March through the current year's September), which identifies the climate response to temperature and precipitation of the tree-ring series.

\section{Results}

Fifty-one tree-ring series from 28 trees at ER were crossdated to create a 444-year (AD 1566-2009) chronology (Fig. 2). Sixty-five series from 31 trees were crossdated to create a 686-year chronology (1324-2009) for PI (Fig. 2). Approximately $70 \%$ of the original collections were included in the final chronologies. The final ER chronology had a series intercorrelation of 0.50 , with a sensitivity of 0.20 , whereas for the PI site, the mean correlation is 0.46 , with a sensitivity of 0.18 . These results are similar to those published by Beier et al. (2008) and for another yellow-cedar chronology available on the International Tree Ring Databank (ITRDB; Roberta Parish (Principal investigator), CANA175, Mount Cain Chronology). Both the ER and PI ring-width series had a pronounced negative trend in growth after the 1950s (Fig. 2); however, the ER series shows a recent recovery (increase) in ring width.
Fig. 2. (A) Excursion Ridge (ER) standard chronology composed of 51 series from 28 trees spanning 444 years, and (B) Pleasant Island (PI) standard chronology of 65 series from 31 trees spanning 686 years. The thin grey line is the annual variation in the series, and the thick black line is the $6 \%$ weighted average. At the bottom of each graph is the number of series in the chronology. Note the steady decrease in ring width throughout the latter portion of the 20th century in both chronologies, with an ongoing decline for PI and a recent recovery for ER.

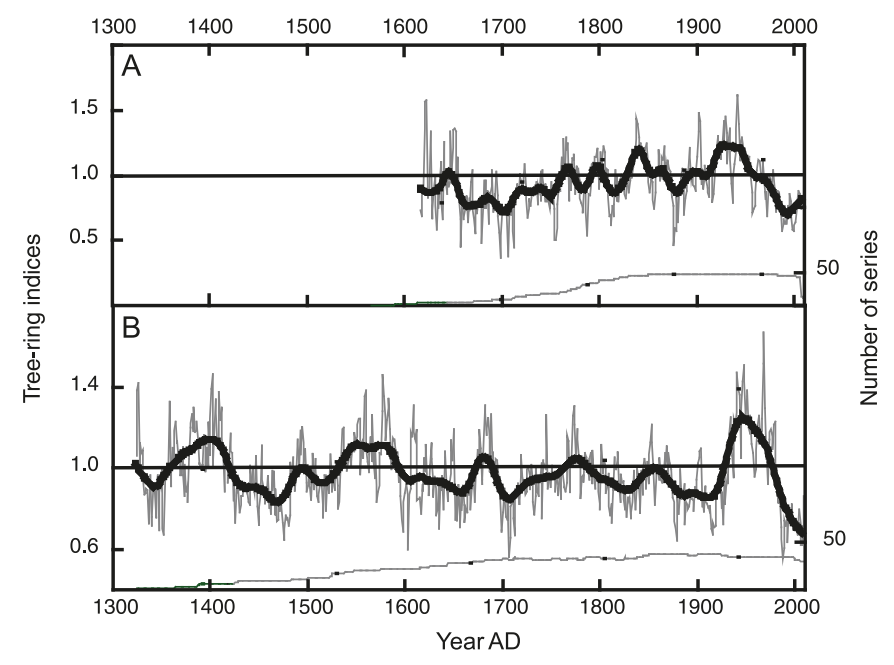

Monthly correlations between the chronologies and the Sitka LIA climate data for the 1832-1876 interval show that growth at the high-elevation ER site was positively related to winter and spring temperatures (Fig. 3A), whereas the growth 
Fig. 3. (A) Correlations for the dendroclimatic year between the standard chronologies (solid bars, Pleasant Island (PI); open bars, Excursion Ridge (ER)) from each site and the late 19th century Sitka temperatures $(1832-1876, n=44)$. The solid horizontal lines denote the $95 \%$ confidence intervals in each panel. Note the strong positive correlations with summer temperatures (June-August) in the ER response. (B) Sitka temperatures after the Little Ice Age (LIA) correlated with the chronologies. Correlations are shown for the 1951-1993 interval $(n=43)$. Note the negative response to warmer temperatures for both PI and ER for most months, with the strongest negative correlations being with winter-spring temperatures.

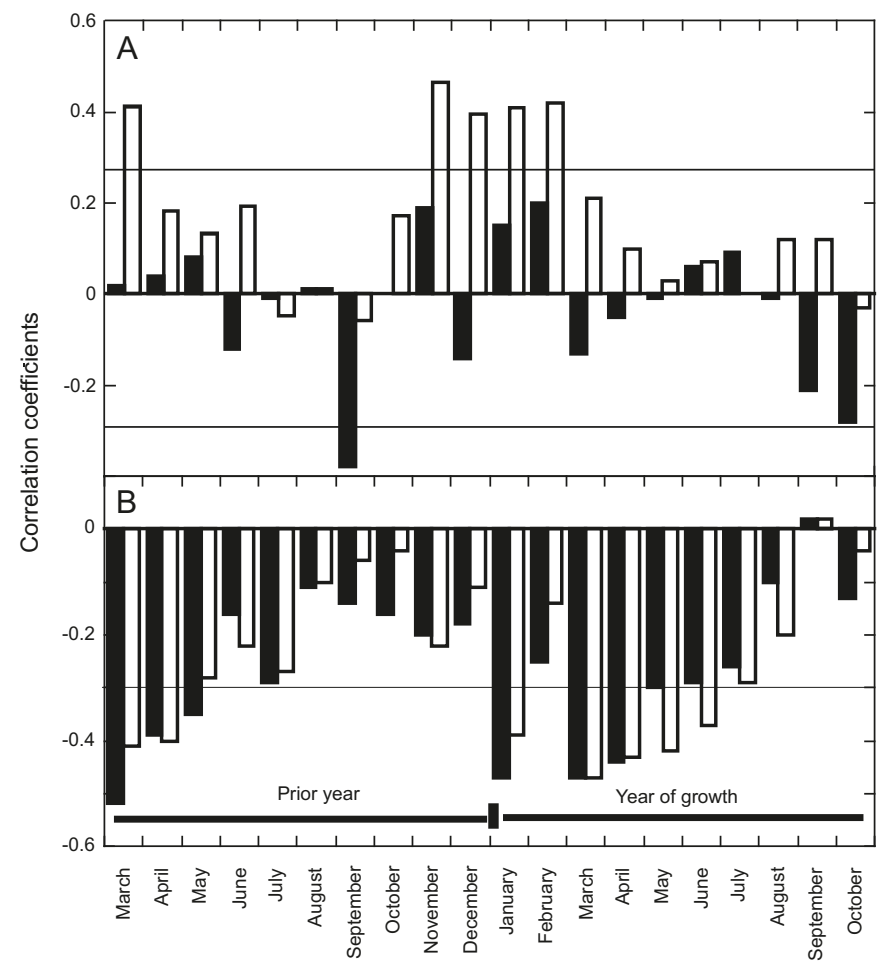

response to temperatures in those months for $\mathrm{PI}$, although positive, are not significant (Fig. 3A). Correlations with the Sitka post-LIA monthly data for the interval 1951 to 1993 for the dendroclimatic year show strong negative correlations (most significant at the 0.05 level) for the months of January through July (Figs. 3B and 4) at both sites. Warmer temperatures for winter through the early growing season have thus become detrimental to tree growth at both sites since 1951 (Fig. 4).

Comparisons with LIA precipitation records from Sitka yielded no significant correlations with either the PI or ER chronology; however, closer to the study sites, the Juneau precipitation records compared favorably with growth in the ring-width chronologies. Total precipitation during the months of March and April, the transitional spring months, is strongly correlated with growth at PI and ER $(r=0.38$, $p=0.009$, and $r=0.45, p=0.002$, respectively) for the interval 1950-1994.

\section{Discussion}

The change in response to temperature of yellow-cedar from $1832-1876$ to $1951-1993$ is profound. Yellow-cedar
Fig. 4. Summary of the climate response shown for the two yellowcedar sites for three intervals. The grey lines represent the annual data, and the black lines represent the $6 \%$ weighted average. Note that during the last 50 years, both sites responded negatively to a relatively large climatic window (January-July). The interval between 1877 and 1900 is unavailable. These results are consistent with the leading hypothesis for yellow-cedar decline, which is linked to warming in Southeast Alaska. In C, the black bars are the correlations between the PI chronology in B and the temperature data in A; the open bars are the correlations between the ER chronology in $\mathrm{B}$ and the temperature data in A.



are now strongly negatively correlated with warm temperatures in the winter through early summer (Fig. 3). The warming at these sites is likely, in part, responsible for the observed decrease in ring widths over the last 50 years (Fig. 2). Previous work suggested that the yellow-cedar is well suited for the cooler LIA, their roots dehardened early under snow cover, allowing them to receive a head start over faster growing species (Schaberg et al. 2005). However, more recently during the decline and warming, less snow cover and early dehardening is leaving them susceptible to freezing damage (Beier et al. 2008).

The strong negative response to temperature in the post1950 period seen in the plot of ring width (Fig. 2A) and the correlation analysis at PI is consistent with the hypothesis that this low-elevation site is more susceptible to climate change based mortality due to earlier loss of snowpack. Based on these relatively simple observations of correlation change over time, it is reasonable to conclude that PI would be more susceptible to decline than ER because of the earlier loss of snowpack at lower elevations or less initial snowfall to the site. The strong negative correlations with temperatures of the spring months (especially March) also support the snowpack hypothesis because of the importance of these months in the timing of thaw (Lamb and Wurtz 2009). Addi- 
tional controls on the timing of snowmelt have been linked to canopy cover (Hennon and Trummer 2001) as at PI; large spacing and open forest allow more solar radiation to reach the soil, forcing early snowmelt.

Beier et al. (2008) conducted an extensive study on yellow-cedar at four groups of declining sites and one healthy group. They concluded that October-December and MarchApril temperatures and precipitations had the greatest effect on growth of declining yellow-cedar. This response is consistent with that of yellow-cedar at the PI site, which respond negatively to warming temperatures in the January-March period. It is important to note, however, that both ER and PI are approximately 33 min latitude $(\approx 60 \mathrm{~km})$ north of the known extent of the decline and well north of the northernmost sites of Beier et al. (2008).

Beier et al. (2008) also determined that healthy stands of cedar were most impacted by climate in the summer months (May-August), which is consistent with the findings at Excursion Ridge, where June-August temperatures held the greatest sway over ring widths during the LIA. They found that stands at higher elevations were more sensitive to the growing season (May-August) temperatures, whereas at lower elevation sites, late winter months were more strongly related to tree growth (Beier et al. 2008).

\section{Conclusions}

Yellow-cedar sites ER and PI have experienced a decrease in growth rates since the mid-20th century. At present, these healthy stands appear unaffected by the decline seen in sites farther to the south; however, a post-1951 downward trend in ring widths is pronounced. Possible decline is most evident and sustained at PI, which is topographically similar to features of sites in the south experiencing the greatest rates of decline (i.e., low elevation, poor drainage, open canopy, low slope (Hennon and Trummer 2001)). Taken together, yellowcedars at the PI site are more susceptible to decline should further warming occur (Shulski and Wendler 2007). Yellowcedars at ER, on the other hand, are less likely to succumb to the decline, despite ER's relatively low elevation (less than $300 \mathrm{~m}$ a.s.l.). ER is on a more rugged, well-drained slope and is a closed canopy forest. Analyses show that yellowcedars at the ER are more sensitive to later season climates (March through May) relative to primarily March for the PI site.

The response to warming and inferred snow cover conditions since 1950 may be unprecedented over the 680-year life of the stand. The change in ER response over the last several decades based on correlation with the Sitka data is strong and of the same magnitude as at the PI site, suggesting a decline at ER that is temporally lagged behind that at PI. The results of this study showing change in the response of yellow-cedar growth at both sites is consistent with the leading hypothesis explaining cedar decline as outlined by Hennon and Trummer (2001). As climate warms and snowfall and the persistence of snow cover is affected, these trees have responded negatively to warming through much of the year and especially in the spring (March and April) months, making them more vulnerable to frost damage of unprotected roots.

\section{Acknowledgements}

We thank Glacier Bay National Park and Preserve and the National Forest Service (US Forest Service Special Use Permit FS-2700-4) for allowing us to sample the yellow-cedar used in this study. This work was supported by the National Science Foundation (ATM-0902799). We are grateful to the National Park Service and Wayne Howell for logistical support. Part of the Excursion Ridge chronology sampling was made possible by a grant from the National Geographic Society. Reviews by Tom Maertens and an anonymous reviewer greatly improved this work. This paper represents LamontDoherty Earth Observatory contribution 7525.

\section{References}

Adams, H.D., Macalady, A.K., Breshears, D.D., Allen, C.D., Stephenson, N.L., Saleska, S.R., Huxman, T.E., and McDowell, N.G. 2010. Climate-induced tree mortality: Earth system consequences. EOS Trans. AGU, 91(17): 153-154. doi:10.1029/ 2010 EO170003.

Allen, C.D., Macalady, A.K., Chenchouni, H., Bachelet, D., McDowell, N., Vennetier, M., Kitzberger, T., Rigling, A., Breshears, D.D., Hogg, E.H., Gonzalez, P., Fensham, R., Zhang, Z., Castro, J., Demidova, N., Lim, J., Allard, G., Running, S.W., Semerci, A., and Cobb, N. 2010. A global overview of drought and heat-induced tree mortality reveals emerging climate change risks for forests. For. Ecol. Manage. 259(4): 660-684. doi:10. 1016/j.foreco.2009.09.001.

Barclay, D.J., Wiles, G.C., and Calkin, P.E. 2009. Holocene glacier fluctuations in Alaska. Quat. Sci. Rev. 71: 22-26.

Beier, C.M., Sink, S.E., Hennon, P.E., D’Amore, D.V., and Juday, G. P. 2008. Twentieth-century warming and the dendroclimatology of declining yellow-cedar forests in southeastern Alaska. Can. J. For. Res. 38(6): 1319-1334. doi:10.1139/X07-240.

Cook, E.R. 1985. A time series analysis approach to tree-ring standardization. Ph.D. thesis, University of Arizona, Tucson, Arizona.

Cook, E.R., and Kairiukstis, L.A. (Editors). 1990. Methods of dendrochronology. Kluwer Academic Publications, Hingham, Massachusetts.

Debreczy, Z., Musial, K., Price, R.A., and Rácz, I. 2009. Relationship and nomenclatureal status of the Nootka cypress (Callitropsis nootkatensis, Cupressaceae). Phytologia, 91: 140-159.

Grissino-Mayer, H.D. 2001. Evaluating cross-dating accuracy: a manual and tutorial for the computer program COFECHA. TreeRing Res. 57: 205-221.

Grove, J.M. 2001. The initiation of the "Little Ice Age" in regions around the North Atlantic. Clim. Change, 48(1): 53-82. doi:10. 1023/A:1005662822136.

Harris, A.S. 1990. Chamaecyparis nootkatensis (D. Don) Spach: Alaska-cedar. In Silvics of North America. Vol. 1. Conifers. Edited by R.M. Burns and B.H. Honkala. USDA Agricultural Handbook 654. pp. 97-102.

Hennon, P.E., and Trummer, L.M. 2001. Yellow-cedar (Chamaecyparis nootkatensis) at the northwest limits of its natural range in Prince William Sound, Alaska. Northwest Sci. 75: 61-71.

Hennon, P.E., D’Amore, D.V., Zeglen, S., and Grainger, M. 2005. Yellow-cedar decline in the north coast forest district of British Columbia. USDA Forest Service, Pacific Northwest Research Station, Research Note PNW-RN-549.

Hennon, P.E., Woodward, B., and Lebow, P. 2007. Deterioration of wood from live and dead Alaska yellow-cedar in contact with soil. For. Prod. J. 57: 23-30. 
Holmes, R.L. 1983. Computer-assisted quality control in tree-ring dating and measurement. Tree-Ring Bull. 43: 69-75.

Jones, P.D., and Bradley, R.S. (Editors). 1992. Climatic variations in the longest instrumental records. In Climate since A.D. 1500. Routledge, London.

Kelsey, R.G., Hennon, P.E., Huso, M., and Karchesy, J.J. 2005. Changes in heartwood chemistry of dead yellow-cedar trees that remain standing for 80 years or more in Southeast Alaska. J. Chem. Ecol. 31(11): 2653-2670. doi:10.1007/s10886-005-7618-6. PMID:16273433.

Lamb, M., and Wurtz, T. (Editors). 2009. Forest health conditions in Alaska - 2008. USDA Forest Service, Alaska Region, Forest Health Protection, Protection Report R10-PR-20.

Little, D.P., Schwarzbach, A.E., Adams, R.P., and Hsieh, C.F. 2004. The circumscription and phylogenetic relationship of Callitrospis and the newly described genus Xanthocyparis (Cupressaceae). Am. J. Bot. 91(11): 1872-1881. doi:10.3732/ajb.91.11.1872. PMID:21652334.

Pojar, J., and MacKinnon, A. (Editors). 1994. Plants of the Pacific Northwest coast. Lone Pine Publishing, Vancouver, British Columbia, Canada.

Ryan, M.G., Harmon, M.E., Birdsey, R.A., Giardina, C.P., Heath, L.S., Houghton, R.A., Jackson, R.B., McKinley, D.C., Morrison, J.F., Murray, B.C., Pataki, D.E., and Skog, K.E. 2010. A synthesis of the science on forests and carbon for U.S. forests. Issues in Ecology, Report Number 13. pp. 1-16.

Schaberg, P.G., Hennon, P.E., D'Amore, D.V., Hawley, G.J., and Borer, C.H. 2005. Seasonal differences in freezing tolerance of yellow-cedar and western hemlock trees at a site affected by yellow-cedar decline. Can. J. For. Res. 35(8): 2065-2070. doi:10. 1139/x05-131.

Schaberg, P.G., Hennon, P.E., D’Amore, D.V., and Hawley, G.J. 2008. Influence of simulated snow cover on the cold tolerance and freezing injury on yellow-cedar seedlings. Glob. Change Biol. 14(6): 1282-1293. doi:10.1111/j.1365-2486.2008.01577.x.

Shulski, M., and Wendler, G. 2007. The climate of Alaska. University of Alaska Press, Fairbanks, Alaska.

Snyder, C., Schultz, M.E., and Lundquist, J. (Editors). 2008. Forest health conditions in Alaska 2007. USDA Forest Service, Forest Health Protection, Protection Report R10-PR-18.

Stokes, M.A., and Smiley, T.L. 1968. An introduction to tree-ring dating. University of Chicago, Chicago, Illinois.

Vose, R.S., Schmoyer, R.L., Steurer, P.M., Peterson, T.C., Heim, R., Karl, T.R., and Eischeid, J.K. 1998. Global Historical Climatology Network, 1753-1990. Data set. Available from http://www.daac. ornl.gov from Oak Ridge National Laboratory Distributed Active Archive Center, Oak Ridge, Tennessee, USA. Previously published as The Global Historical Climatology Network: Long-Term Monthly Temperature, Precipitation, Sea Level Pressure, and Station Pressure Data, ORNL/CDIAC-53, CDIAC NDP-041, Carbon Dioxide Information Analysis Center, Oak Ridge National Laboratory, Oak Ridge, Tennessee, U.S.A., 1992. doi:10.3334/ ORNLDAAC/220.

Westfall, J., and Ebata, T. 2009. 2008 Summary of forest health conditions in British Columbia. British Columbia Ministry of Forests and Range, Pest Management Report No. 15. Available from http://www.for.gov.bc.ca/hfp/health/overview/2008.htm [accessed 6 March 2012]. 